\title{
Dial organic carbon fluctuations in a mangrove tidal creek in Sepetiba bay, Southeast Brazil
}

\author{
Rezende, CE. ${ }^{\mathrm{a} *}$, Lacerda, LD. ${ }^{\mathrm{b}}$, Ovalle, ARC. ${ }^{\mathrm{a}}$ and Silva, $L F F .^{\mathrm{b}}$

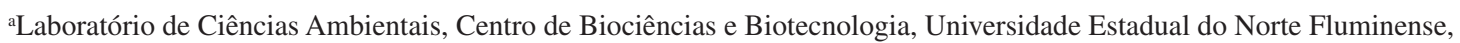 \\ Av. Alberto Lamego 2.000, CEP 28.015-620, Campos dos Goytacazes, RJ, Brasil \\ ${ }^{b}$ Departamento de Geoquímica, Universidade Federal Fluminense, \\ Morro do Valonguinho s/n, CEP 24.020-007, Niterói, RJ, Brasil \\ *e-mail: crezende@uenf.br
}

Received January 27, 2006 - Accepted July 24, 2006 - Accepted November 30, 2007

(With 5 figures)

\begin{abstract}
The carbon (C) concentration and flux, as dissolved organic carbon (DOC), particulate organic carbon (POC) and macrodetritus (MD), were quantified through 4 tidal cycles in a mangrove tidal creek in Southeastern Brazil. DOC was the major fraction of the total $\mathrm{C}$ concentration, accounting for 68 and $61 \%$ of the total $\mathrm{C}$ concentration during ebb and flood periods respectively. Concentrations of DOC ( $\mathrm{Ebb}=3,41 \pm 0,57 \mathrm{mgC} . \mathrm{L}^{-1}$ and Flood $\left.=3,55 \pm 0,76 \mathrm{mgC} . \mathrm{L}^{-1}\right)$ and POC $\left(\mathrm{Ebb}=1,73 \pm 0,99 \mathrm{mgC} \cdot \mathrm{L}^{-1}\right.$ and Flood $\left.=1,28 \pm 0,45 \mathrm{mgC} \cdot \mathrm{L}^{-1}\right)$ were relatively similar during the four tidal cycles. Macrodetritus presented a wide variation with concentration peaks probably related to external forces, such as winds, which enrich the ebb flow with leaf litter. DOC and POC fluxes depended primarily on tidal and net water fluxes, whereas MD fluxes were not. The magnitude of the DOC and POC fluxes varied with the area flooded at high tide, but not the MD fluxes. DOC was the major form of carbon export to Sepetiba Bay. During the four tidal cycles, the forest exported a total of $1,2 \mathrm{~kg}$ of organic carbon per ha, mostly as DOC (60\%), followed by POC (22\%) and MD (18\%).
\end{abstract}

Keywords: dissolved organic carbon, macrodetritus, mangrove tidal creek, particulate organic carbon.

\section{Flutuações diurnas do carbono orgânico em um canal de maré na Baía de Sepetiba, SE Brasil}

\section{Resumo}

As concentrações e fluxos de carbono orgânico sob forma de carbono orgânico dissolvido (COD), carbono orgânico particulado (COP) e macrodetritos (MD) foram quantificadas durante 4 ciclos de maré em canal de maré na Floresta Experimental de Itacuruçá, Baía de Sepetiba, RJ, litoral sudeste do Brasil. COD foi a fração mais importante para a concentração total de carbono orgânico, contribuindo com 68 e $61 \%$ da concentração total de $C$ nos períodos de maré vazante e enchente, respectivamente. As concentrações de COD (vazante $=3.41 \pm 0.57 \mathrm{mgC} . \mathrm{L}^{-1} \mathrm{e}$ enchente $=3.55 \pm 0.76 \mathrm{mgC} . \mathrm{L}^{-1}$ ) e COP $($ vazante $=$ $1.73 \pm 0.99 \mathrm{mgC} . \mathrm{L}^{-1} \mathrm{e}$ enchente $\left.=1.28 \pm 0.45 \mathrm{mgC} . \mathrm{L}^{-1}\right)$ foram similares durante os 4 ciclos de maré. $\mathrm{A}$ fração macrodetritos apresentou uma ampla variabilidade com máximos de concentração relacionados a fatores externos como ventos, que enriqueceram as águas de vazante com macrodetritos. A magnitude dos fluxos de COD e COP, mas não os de macrodetritos, relacionaram-se com os fluxos de água e a conseqüente área inundada pela maré. A fração COD foi a mais importante forma de exportação de carbono orgânico pelo manguezal. Durante os 4 ciclos monitorados, a floresta exportou um total de $1.2 \mathrm{~kg}$ de carbono orgânico, $60 \%$ sob forma de COD, seguido pelo COP (22\%) e pela fração macrodetritos (18\%).

Palavras-chave: carbono orgânico dissolvido, macrodetritos, carbono orgânico particulado, manguezais.

\section{Introduction}

Mangrove ecosystems dominate most tropical coasts. They grow along the depositional environments in protected coastal areas, in estuaries and lagoons, where, once established, they accelerate sediment accretion, by trapping suspended matter and decreasing erosion. Mangroves are exposed to tidal fluctuations and corresponding variability in salinity and water sources. Therefore, the dynamics of water and inorganic and organic compounds depend on interactions controlled by tides, runoff, seasonal fluctuations, and meteorological events (Ovalle et al., 1990; Woodroffe, 1985a,b).
Many studies have focused on the fate of particulate organic carbon (POC) and dissolved organic carbon (DOC) in temperate estuaries and salt marshes (Taylor and Allanson, 1995). However, the fate of organic carbon in mangrove ecosystems has been mostly studied based on a single component analysis with most studies dealing with macrodetritus (MD) balances only. Few studies monitored the transport of the 3 carbon forms simultaneously. Therefore no generalisations regarding export/import of carbon can be made, although the productivity of mangrove ecosys- 
tems has been recognised as one of the highest among natural ecosystems.

Particulate (POC) and dissolved organic carbon (DOC) and macrodetritus (MD) distributions frequently show large temporal and spatial variability. Associated with this, some environmental parameters such as coastal geomorphology, forest structure, climatology, hydrology, microbiological activity and sources of the organic carbon itself introduce large variability in exchange rates with adjacent coastal waters (Boto and Bunt, 1981; Twilley, 1985; Woodroffe, 1985b; Hemminga et al., 1994).

Biological and chemical processes of coastal ecosystems act to modify materials import, export and accumulation rate between the continent and ocean (Rezende et al., 1990; Ovalle, et al., 1990). Mangroves and salt marshes have been constantly cited in the scientific literature as major contributors of organic matter to coastal food chains (Lee, 1995). However, the relative contribution of the different organic carbon fractions (POC, DOC and MD) has not been adequately evaluated. Few simultaneous determinations of these fractions have been attempted. These gaps in the literature hamper generalisations regarding the role of mangroves as exporters or importers of organic carbon (Lee, 1995).

In this study, we compare the POC, DOC and MD fluxes through a small mangrove tidal creek in Sepetiba Bay, Rio de Janeiro, Brazil (Lat. 22 ${ }^{\circ} 54^{\prime} 06^{\prime \prime}$ S and $23^{\circ} 04^{\prime} 18^{\prime \prime} \mathrm{S}$, and Long. $43^{\circ} 33^{\prime} 44^{\prime \prime} \mathrm{W}$ and $44^{\circ} 02^{\prime} 30^{\prime \prime} \mathrm{W}$; Figure 1 ) in order to determine the relative importance of each carbon fraction to the total carbon flow to and from adjacent coastal waters.

\section{Study Area}

The study was conducted at the Itacuruçá Experimental Forest (IEF), located along the North shore
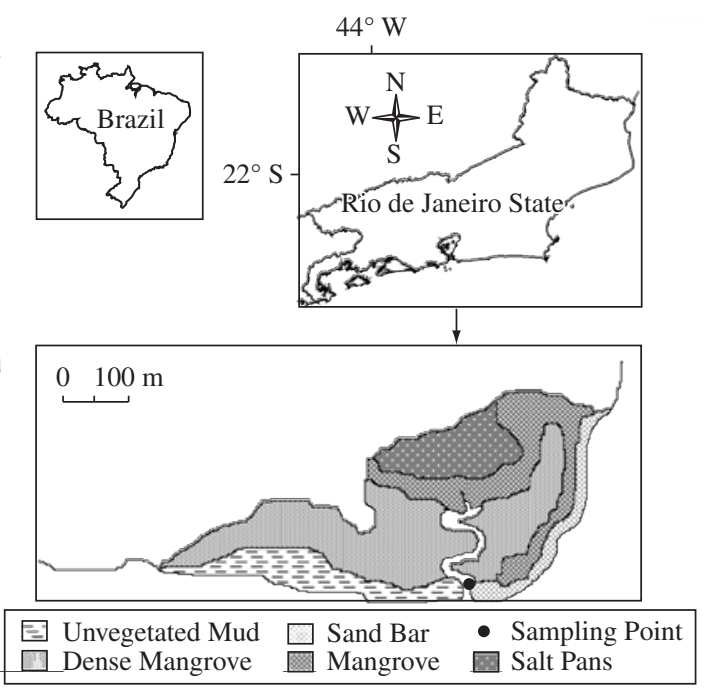

Figure 1. Location and characteristics of the Itacuruçá Experimental Forest, Sepetiba Bay, SE Brazil, and sampling point in the tidal creek (Adapted from Aragon et al., 1999). of Sepetiba Bay, approximately $100 \mathrm{~km}$ from Rio de Janeiro (Figure 1). Sepetiba Bay is a $450 \mathrm{~km}^{2}$ coastal lagoon, with average depth of $6.0 \mathrm{~m}$ and tidal range of less than $2.0 \mathrm{~m}$. Sepetiba drainage basin harbors an industrial park, with over 400 industries, and a population of about 2.2 million. Notwithstanding, the IEF is free of potential contamination from these anthropogenic activities.

Mangroves cover about $38 \mathrm{~km}^{2}$, mostly as fringe forests along the Bay's North and Northeastern coasts. The IEF is a typical fringe mangrove forest with Rhizophora mangle Linnaeus (1753), as dominant species, although isolated trees of the black mangrove (Avicennia schaueriana Stapf and Leechman ex. Moldenke 1939) and of the white mangrove (Laguncularia racemosa (Linnaeus) Gaertner.f. (1805)) occur throughout the forest. The IEF has an area of approximately 10 ha. At the seaward edge, the forest is lined by a strip of mud flats about $70 \mathrm{~m}$ wide, frequently exposed during low tide. At the landward edge, the forest is bordered by marine sands dominated by stunted $L$. racemosa trees and the fern Achrosticum aureum Linnaeus (1753). The IEF is drained by a tidal creek running almost perpendicular to the shore and land. This creek is responsible for over $90 \%$ of the water exchange at the IEF (Ovalle et al., 1990). Creek depth depends on tides and ranges from $0.6 \mathrm{~m}$ to $2.6 \mathrm{~m}$. Average air temperatures range between $18{ }^{\circ} \mathrm{C}$ in winter and $23{ }^{\circ} \mathrm{C}$ in summer. Annual rainfall is c.a. 2,300 mm, with a typical rainy season in December and a dry season in July. The IEF forest structure has been studied by Silva et al. (1991). In summary, average tree density is 4,510 trees. $\mathrm{ha}^{-1}$, with an average height of $6 \mathrm{~m}$ and an average diameter of $8 \mathrm{~cm}$. Basal area is $22 \mathrm{~m}^{2} \cdot \mathrm{ha}^{-1}$ and the total biomass is 82 t.ha $^{-1}$, distributed between aboveground ( 65.4 t.ha-1) and below ground (16.3 t.ha-1) biomass. Freshwater to the IEF is from groundwater and rainwater, and the inundation pattern is controlled by tidal amplitude. More details on forest structure, hydrochemistry and carbon isotopic composition of mangrove material has been published elsewhere (Ovalle et al., 1990; Silva et al., 1990, 1991; Lacerda et al, 1988).

\section{Material and Methods}

The changes in organic carbon concentrations in the tidal creek waters as well as major hydrological parameters were monitored through four complete tidal cycles in a fixed sampling station at the mouth of the creek (Figure 1). POC, DOC and MD samples were collected every 30 minutes in the central area of the creek during the winter, characterised as the dry period with creek water salinity varying between 24 up to 32 . The effects of seasonal variability cannot be evaluated in this study but litterfall rates, groundwater inputs to the forest and interstitial water turnover rate increase during the rainy season (Silva, 1988; Ovalle et al., 1990).

Water samples for POC and DOC analysis were collected using a 5 L Van Dorn bottle. All water samples were filtered in the field and frozen. Macrodetritus were collected using a special kind of collector, made of a 
square frame $\left(0.25 \mathrm{~m}^{2}\right)$; with nylon net of $1.0 \mathrm{~mm}$ mesh size fixed on a pole, but allowed to rotate according to water flow direction, adapted from Bach et al. (1986).

Macrodetritus included different plant parts (leaves, branches and reproductive parts) and were cleaned using local seawater and at the laboratory with distilled water.

POC in suspended matter samples, were separated using a pre-weighted GF/C filter. Total organic carbon concentration in POC and MD, were determined by dichromate oxidation following Stricland and Parsons (1972). For all POC determinations a blank of clean filters were analysed simultaneously. Reproducibility of POC and MD analysis were estimated using 4 replicates, giving coefficients of variation smaller than $5 \%$. DOC was determined directly in the filtered samples preserved in phosphoric acid $\left(10 \% \mathrm{H}_{3} \mathrm{PO}_{4} ; 50 \mu \mathrm{L} . \mathrm{mL}^{-1}\right)$. Filtrate was stored refrigerated in amber bottles. DOC analyses were performed after further sample acidification $(2 \mathrm{~N} \mathrm{HCl})$ and sparing with ultra pure air, by high temperature catalytic oxidation with a Dohrman DOC-190. The reproducibility of DOC analysis was estimated using 3 replicates, giving coefficients of variations smaller than $2 \%$.

Flux rates were continuously monitored using a General Oceanics ${ }^{\circledR}$ current meter installed at the center of the creek and $0.3 \mathrm{~m}$ above the bottom. Similar to the organic carbon sampling strategy current velocity and water level were measured every 30 minutes. A microtopographic mapping of the forest floor (Ovalle, 1992), allowed the estimation of flooded forest area relative to creek depth at each sampling interval.

\section{Results and Discussion}

A summary of the study results are shown in Table 1. During flood periods, the maximum flooded mangrove area ranged from 6.6 to 9.0 ha, with maximum creek depth reaching $1.8 \mathrm{~m}$. The maximum flooded area (9.0 ha) included a low L. racemosa mangrove forest and salt pans located behind the $R$. mangle forest. Highest current velocities occurred during flood periods. Maximum water fluxes ranged from 108 to $380 \mathrm{dm}^{3} / \mathrm{s}$ during flood periods, whereas during ebb periods maximum fluxes were smaller, ranging from 80 to $350 \mathrm{dm}^{3} / \mathrm{s}$, depending on the tide (Figure 2).

Water flux fluctuations during the four tidal cycles showed that $82 \%$ of the total amount of water flowing during each cycle was moved during only $42 \%$ of the tidal cycle time. This agrees with hydrochemical results obtained by Ovalle et al. (1990) for the same forest. Discharge pulses occur at the end of flood periods and at the beginning of ebb periods. The tidal flow will always occur in a matter of minutes, when the pressure gradient changes direction and a turbulent mixing occurs affecting the nepheloid layer at the sediment-water interface. This may eventually affect POC concentrations due to ressuspension of bottom sediments and DOC through migration of C-enriched porewaters (Lee, 1995). The water dynamics during the four tidal cycles were similar

Table 1. Major variables measured at the mangrove tidal creek at the Itacuruçá Experimental forest, SE Brazil. Mean (X), standard deviation (SD) and ranges, relative to 4 tidal cycles.

\begin{tabular}{|c|c|c|c|c|c|c|}
\hline $\begin{array}{c}\text { Tidal } \\
\text { Period }\end{array}$ & $\begin{array}{c}\text { Flooded area } \\
\text { (ha) }\end{array}$ & $\begin{array}{c}\text { Creek depth } \\
(\mathbf{m})\end{array}$ & Flux $\left(\mathrm{dm}^{3} \cdot \mathrm{s}^{-1}\right)$ & DOC (mgC.L $\left.{ }^{-1}\right)$ & POC (mgC.. $\left.\mathbf{L}^{-1}\right)$ & MD $\left(\mathbf{m g C} . \mathbf{L}^{-1}\right)$ \\
\hline \multicolumn{7}{|l|}{ Ebb } \\
\hline $\mathrm{X} \pm \mathrm{SD}$ & $3.30 \pm 2.54$ & $1.36 \pm 0.25$ & $-72 \pm 117$ & $3.41 \pm 0.57$ & $1.73 \pm 0.99$ & $0.75 \pm 0.94$ \\
\hline range & 0 to 8.67 & 0.81 to 1.82 & -1 to -346 & 2.30 to 4.60 & 1.20 to 3.29 & 0 to 3.24 \\
\hline \multicolumn{7}{|l|}{ Flood } \\
\hline $\mathrm{X} \pm \mathrm{SD}$ & $4.34 \pm 2.65$ & $1.45 \pm 0.27$ & $+78 \pm 125$ & $3.55 \pm 0.76$ & $1.28 \pm 0.45$ & $0.93 \pm 1.20$ \\
\hline range & 0 to 9.04 & 0.81 to 1.85 & +1 to +380 & 2.30 to 5.30 & 0.80 to 2.60 & 0 to 4.34 \\
\hline
\end{tabular}
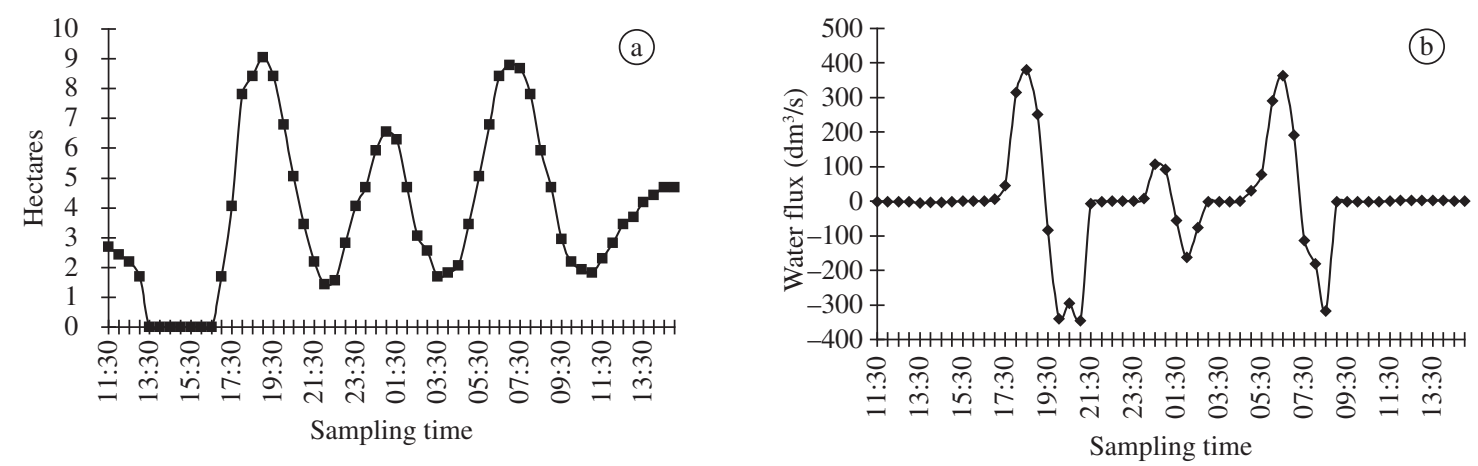

Figure 2. Flooded area (a) and water flux (b) during the tidal cycles at the Itacuruçá Experimental Forest. 
to the dynamics observed during three years of monitoring at this site (Rezende, 1988; Lacerda et al., 1988; Ovalle et al., 1990; Ovalle, 1992; Silva, 1992).

The variation of carbon concentrations in the three different fractions are presented in Figure 3. The larger proportion of the total organic carbon concentration was in the DOC fraction. DOC concentrations were rather constant throughout the cycles, with average concentrations of 3.4 and $3.6 \mathrm{mgC} . \mathrm{L}^{-1}$ during ebb and flood periods respectively. Variation of DOC concentrations showed no relationship with tidal period. These concentrations averaged 68 and $61 \%$ of the total carbon concentration during ebb and flood periods respectively.

Average POC concentrations were higher during ebb periods, ranging from 1.2 to $3.3 \mathrm{mgC} . \mathrm{L}^{-1}$, whereas during flood periods, average of POC concentrations ranged from 0.8 to $2.6 \mathrm{mgC} . \mathrm{L}^{-1}$. Average POC concentrations were 1.4-times higher and maximum concentrations 2.3-times higher, during ebb periods (Table 1) and accounted for 17 and $23 \%$ of the total carbon concentration. Since ebb-period POC in this creek is over $80 \%$ of mangrove origin (Rezende et al., 1990), these
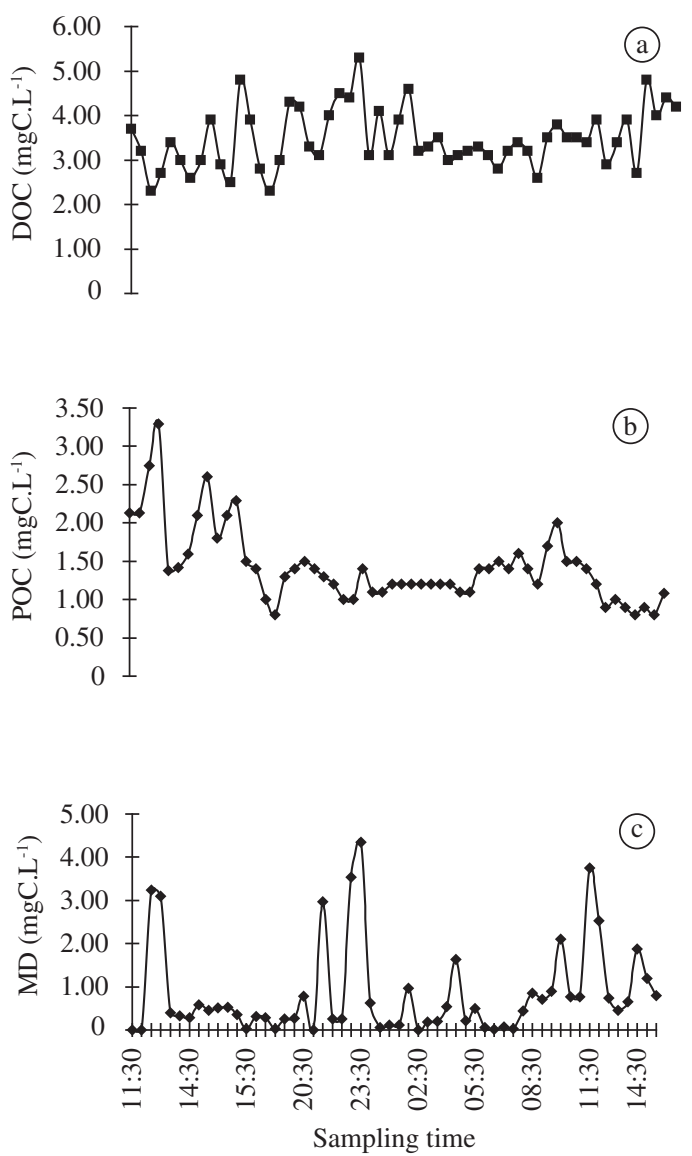

Figure 3. Variations of organic carbon concentrations as dissolved organic carbon (a), particulate organic carbon (b) and macrodetritus (c) during four tidal cycles at the Itacuruçá Experimental Forest. higher concentrations during ebb periods imply a net export of mangrove POC to adjacent coastal waters. A peak concentration of $6.1 \mathrm{mgC} . \mathrm{L}^{-1}$, occurred with very low creek depth, suggesting remobilization of bottom sediments, when water flux changes direction, as suggested by Lee (1995).

The DOC/POC ratio in the mangrove creek was relatively constant (2.2 and 2.5 for ebb and flood period respectively), showing that DOC is an important component in organic carbon balance studies in this ecosystem. This ratio was found to be the around 1.4 in main rivers discharging into Sepetiba Bay, but with a larger variation (0.5 to 2.0) (Rezende, 1993). Although the DOC concentration in the four major rivers of Sepetiba Bay are lower than in the mangrove areas, these rivers can affect the DOC and POC ratios in the Bay. These rivers together contribute $96 \%$ of fresh water and particulate matter entering the Bay and can represent a significant source of organic material derived from continental soils and terrestrial vegetation (Rezende, 1993). It is clear however, that the mangrove forest can produce a localised enrichment of DOC in bay waters adjacent to IEF.

Carbon concentrations as MD showed larger variation when compared with POC and DOC. Average MD concentration for the 4 tidal cycles varied from 0.8 and $0.9 \mathrm{mgC} . \mathrm{L}^{-1}$, during ebb and flood periods respectively. However, isolated peaks as high as $4.5 \mathrm{mgC} . \mathrm{L}^{-1}$, occurred but were not related to tidal fluctuation. This resulted in large variability (125\%) suggesting that significant amounts of MD can be mobilised instantaneously and may be transported during ebb periods to adjacent areas, where it can be degraded and later becomes a source of POC and/or DOC to the mangrove itself. On the other hand, MD is more likely a significant source of carbon to coastal marine sediments. Boto and Bunt (1981) proposed MD to be the most important carbon fraction transported in an Australia mangrove system and carbon isotopic studies at the IEF, also showed that over $99 \%$ of the $\mathrm{C}$ buried in mangrove sediments is derived from mangrove MD (Lacerda and Rezende, 1987; Lacerda, 1998). The MD transport is limited by litter fall production, mangrove structure, deposited leaves on the mangrove soil surface, activity of crabs, and tidal energy (Kjerfve, 1990; Silva, 1988; Robertson, 1986).

Variations of the DOC, POC and MD fluxes through the tidal creek during the four tidal cycles are showed in Figure 4. Fluxes of DOC and POC presented peaks simultaneous with water discharge pulses. However, MD fluxes exhibited peaks simultaneous with discharge pulses only during the ebb tide, except during the first cycle when a small peak occurred during flood tide, probably as a result of washing out the mud flats. Silva et al. (1993) showed that litter transport in this same creek is largely influenced by the occurrence of mangrove MD deposited on mud flats located in front of the mangrove forest fringe, which frequently returns to the creek with the incoming tide. 
Carbon fluxes correlate with the inundated forest area (Figures 5a and 5b). During flood periods (Figure 5a) the fluxes of the three different $\mathrm{C}$ fractions show a significant positive exponential correlation $(\mathrm{P}<0.01)$ with the inundated area, in particular DOC and POC that are extremely dependent on water fluxes. During the ebb period (Figure 5b) however, the dynamic of inundation pulses is more important than the total surface area flooded. At the early stage of the flood period when about 3 ha of the IEF are inundated, the magnitude of $\mathrm{C}$ fluxes varied very little, since this area includes mostly the creek itself and marginal sediments. When the flooded area extends from 3 to 8 ha and therefore including the dense mangrove forest, the $\mathrm{C}$ transported through the creek showed

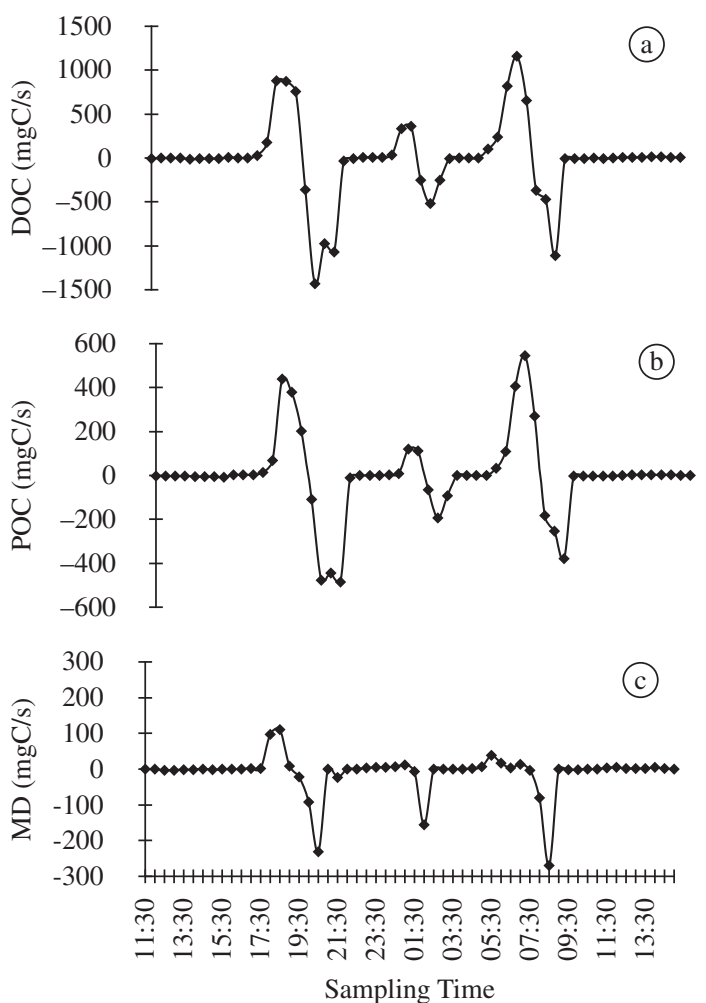

Figure 4. Variations of organic carbon fluxes as dissolved organic carbon (a), particulate organic carbon (b) and macrodetritus (c) during four tidal cycles at the Itacuruçá Experimental Forest. a strong increase. This threshold-like behavior has been shown as an important nutrient transfer mechanism from mangroves to tidal creeks (Cohen et al., 2004). When flooded areas are larger than 8 ha, however, no increase in $\mathrm{C}$ fluxes is verified, since the new flooded areas include salt pans and some of the marginal sands that due to its low $\mathrm{C}$ content promoted a marked dilution in carbon fluxes.

The MD fluxes show a weaker correlation with the extension of the flooded area when salt pans data are included. However, if only creek and dense mangrove zones are included (flooded area $<8$ ha), the correlation turns more significant, since litter fall is directly related to high tree density and productivity of these areas (Silva et al., 1991). Moreover, strong winds and crab activity may significantly affect MD transfer to the creek, independent of the flooded area (Silva et al, 1993; Silva, 1994).

The amount of organic carbon transported during the four cycles studied and the total of the entire sampling period are showed in the Table 2. The pattern observed during ebb and flood periods was similar for DOC and POC alternating net flux of export (-) and import (+), depending on tidal flow direction. MD however, was exported from the forest even during one cycle with net water import, probably in response to winds. DOC presented the highest flux values per cycle, being 2 to 6 times and 2 to 18 times higher than the amount of POC and MD respectively, for each cycle. However, the total amount of carbon exported from the mangroves for the four tidal cycles period was dominated by MD $(0.99 \mathrm{~kg})$, followed by DOC $(0.76 \mathrm{~kg})$. There was nearly no net export of POC from this forest during the four tidal cycles.

When the amount of carbon transported is normalised for area (kg.ha-1; Table 2), however, DOC clearly dominates the carbon export, followed by POC and MD. This is due to the relationship between DOC and POC with flooded area. Of interesting notice is the net import of water during the four cycles, strengthening the role of the forest as a net exporter of organic carbon. Earlier studies showed little agreement in considering mangroves as net exporters or importers of organic carbon. However, the high productivity of mangroves has often been related to the exportation of organic material to coastal waters (Alongi et al., 2004). The applicability of this generalisation is hampered by the existence of only a few studies that simultaneously analysed the transport

Table 2. Mass balance of organic carbon as dissolved organic carbon (DOC), particulate organic carbon (POC) and macrodetritus (MD), after four tidal cycles.

\begin{tabular}{|c|c|c|c|c|c|c|c|}
\hline Cycle & $\begin{array}{c}\text { DOC } \\
(\mathrm{kg})\end{array}$ & $\begin{array}{c}\text { POC } \\
(\mathrm{kg})\end{array}$ & $\begin{array}{l}\text { MD } \\
(\mathrm{kg}) \\
\end{array}$ & $\begin{array}{c}\text { DOC } \\
\left(\text { kg.ha-1 }^{-1}\right)\end{array}$ & $\begin{array}{c}\text { POC } \\
\left(k \text {.ha }^{-1}\right)\end{array}$ & $\begin{array}{c}\text { MD } \\
\left(\mathrm{kg.ha}^{-1}\right)\end{array}$ & $\begin{array}{c}\text { Water } \\
\left(\mathbf{m}^{3}\right)\end{array}$ \\
\hline $1^{\text {st }}$ & +4.81 & +1.93 & +0.38 & +0.64 & +0.26 & +0.04 & $+1,771$ \\
\hline $2^{\text {nd }}$ & -5.64 & -2.31 & -0.61 & -1.17 & -0.50 & -0.12 & $-1,553$ \\
\hline $3^{\text {rd }}$ & +3.49 & +1.81 & -0.15 & +0.31 & +0.19 & -0.04 & $+1,184$ \\
\hline $4^{\text {th }}$ & -3.42 & -1.46 & -0.61 & -0.51 & -0.21 & -0.09 & $-1,083$ \\
\hline$\Sigma$ & -0.76 & -0.03 & -0.99 & -0.73 & -0.26 & -0.21 & +319 \\
\hline
\end{tabular}


(a)
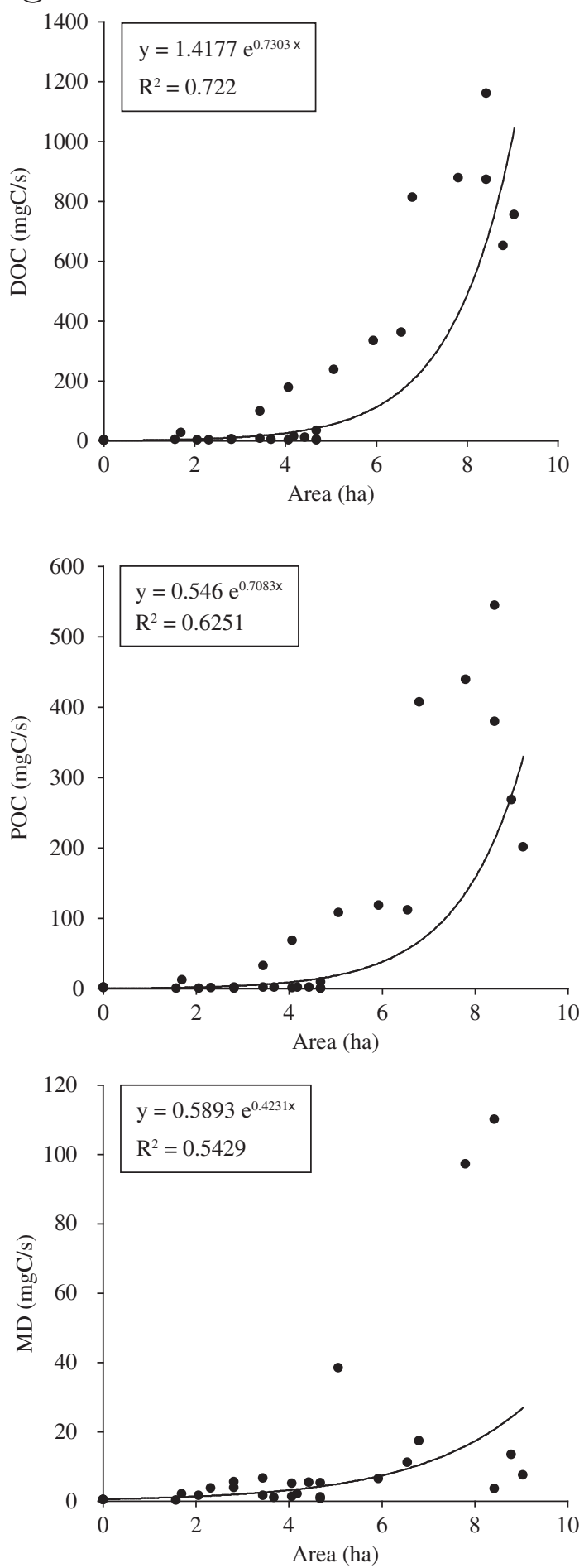

(b)
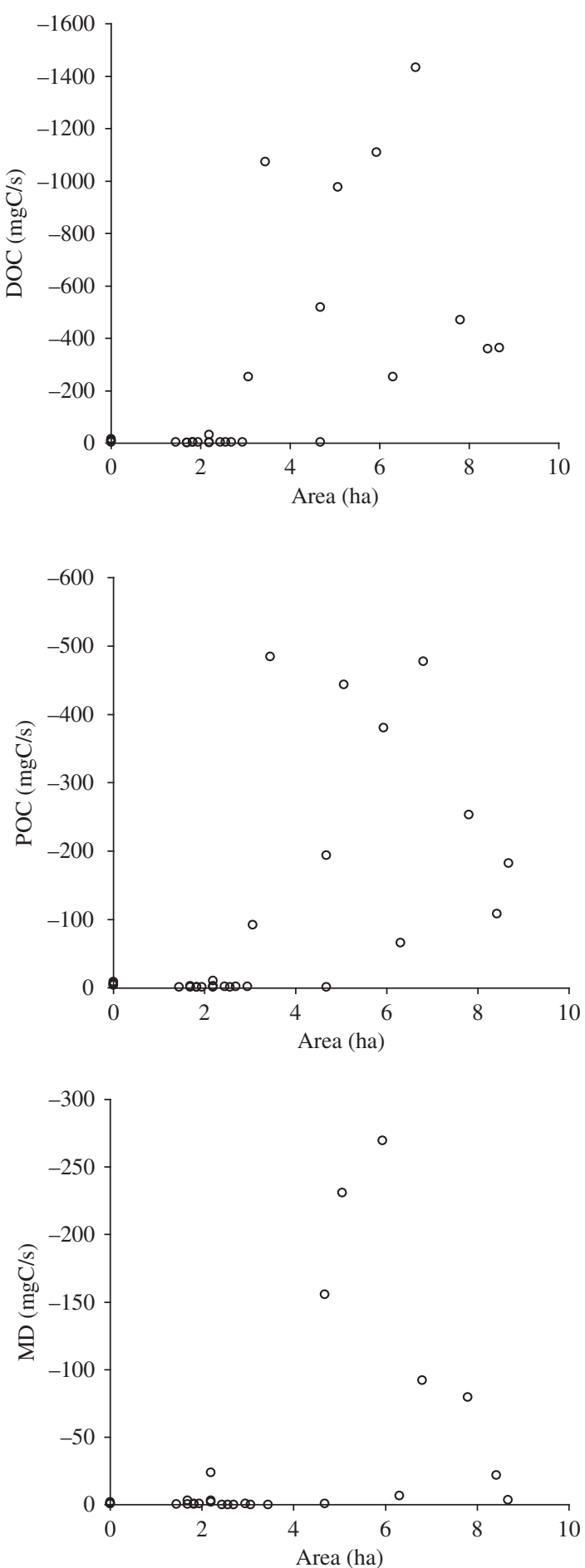

Figure 5. Trends of organic carbon fluxes and inundated area during flood a) closed circles and ebb b) open circles periods of the Itacuruçá Experimental Forest.

of all fractions of organic carbon. In this study, notwithstanding its short duration, we have shown that different fractions of the total organic carbon behave differently and, most important, are controlled by different envi- ronmental variables (e.g. flooded area extension, mostly DOC; vs external forces, such as wind, mostly MD). On the other hand, our results agree with salt marsh studies (Taylor and Allanson, 1995; Williams et al., 1992; Dame 
et al., 1991) and a few mangrove studies (Twilley, 1985; 1988; Alongi et al., 2004), highlighting the importance of DOC as the major organic carbon fraction exported from mangroves.

Acknowledgments - This study was partially supported by FAPERJ - PRONEX (Fundação Carlos Chagas Filho de Amparo à Pesquisa do Estado do Rio de Janeiro) and a contribution of "Instituto do Milênio - Estuários" Program from CNPq (Proc.\# 420.050/2005-1). The authors thank the various undergraduate and graduate students for help with field work and two anonymous reviewers for the critical comments of the manuscript. We are also indebt to Universidade Rural do Rio de Janeiro that provided logistic facilities for field work. CER (Proc.\#306.188/2004-0), LDL and ARCO are supported by CNPq and CER by FAPERJ (Proc.\# E-26/151.949/2004).

\section{References}

ALONGI, DM., SASESUMAR, VC., CHONG, J., PFITZNER, LA., TROTT, LA, TIRENDI, F., DIXON, P. and BRUJNSKILL, GL., 2004. Sediment accumulation and organic material flux in a managed mangrove ecosystem: estimates of land-oceanatmosphere exchange in peninsular Malaysia. Mar. Geol. vol. 208 , no. $2-4$, p. 383-402.

ARAGON, GT., OVAlle, ARC., CARMOUZE, JP., 1999. Porewater Dynamics and The Formation Of Iron Sulfides In A Mangrove Ecosystem, Sepetiba Bay, Brazil. Mangroves and Salt Marshes, Netherlands, vol. 3, no. 2, p. 85-93.

BACH, ST., THAYER, GM. and LACROIX, MW., 1986. Export of detritus from eelgrass (Zoostera marina) beds near Beaufort, North Carolina, USA. Mar. Ecol. Progr. Ser., vol. 28, p. $265-278$.

BOTO, KG. and BUNT, JS., 1981. Tidal export of particulate organic matter from a Northern Australian mangrove system. Estuar. Coast. Shelf Sci., vol. 13, p. 247-255.

COHEN, MCL., LARA, RJ., SZLAFSZTEIN, C. and DITTMAR, T., 2004. Mangrove inundation and nutrient dynamics from a GIS perspective. Wetlands Ecol. Manag., vol. 12 , no. 3 , p. $81-86$

DAME, RF., SPURRIER, J., WILLIAMS, TM., KJERFVE, B., ZINGMARK, RG., WOLAVER, TG., CHRZANOWSKI, TH., MCKELLAR, HN. and VERNBERG, FJ., 1991. Annual material processing by a salt marsh estuarine basin in South Carolina, USA. Mar. Ecol. Progr. Ser, vol. 72, p. 153-166.

HEMMINGA, MA., SLIM, FJ., KAZUNGU, J., GANSSEM, GM., NIEUWENHUIZE, J. and KRUYT, NM., 1994. Carbon outwelling from a mangrove forest with adjacent seagrass beds and coral reefs (Gazi Bay, Kenya). Mar. Ecol. Progr. Ser, vol. 106, p. 291-301.

KJERFVE, B., 1990. Manual for Investigation of Hydrological Processes in Mangrove Ecosystems. UNESCO/UNDP, New Delhi, India, 79p.

LACERDA, LD. and REZENDE, CE., 1987. Metal geochemistry in mangrove sediments. Proceedings of the I Simpósio sobre Ecossistemas da Costa Sudeste-Sul do Brasil. ACIESP, São Paulo, vol. III, p. 123-131.

LACERDA, LD., MARTINELLI, LA., REZENDE, CE., OVALLE, ARC., VICTORIA, RL., SILVA, CAR. AND NOGUEIRA, FB., 1988. The fate of trace metals in suspended matter in a mangrove creek during a tidal cycle. Sci. Tot. Environ., vol. 75, p. 69-180.

LACERDA, LD., 1998. Trace metals biogeochemistry and diffuse pollution in mangrove ecosystems. Mangrove Ecosystems Occasional Papers, vol. 2, p. 1-65. International Society for Mangrove Ecosystems (ISME), Okinawa.

LEE, SY., 1995. Proceedings of the International Conference held at The Hong Kong University of Science and Technology, Edited by Yuk-Shan Wong and Nora F. Y. Tam. Mangrove outwelling: A review. Hydrobiol., vol. 295, p. 203-212.

OVALLE, ARC., REZENDE, CE., LACERDA, LD. and SILVA, CAR., 1990. Factors affecting the hydrochemistry of a mangrove tidal creek, Sepetiba Bay, Brazil. Estuar. Coast. Shelf Sci., vol. 30, p. 639-650.

OVALLE, ARC., 1992. Hidroquímica de um Canal de Maré em um Manguezal de Itacurussá, Baía de Sepetiba, RJ. 159p. (PhD Thesis) - Universidade Federal de São Carlos, SP.

REZENDE, CE., 1988. Balanço de Matéria Orgânica e Metais Pesados em um Ecossistema de Mangue, Baía de Sepetiba, RJ., 96p. (MSc Dissertation) - Universidade Federal Flluminense.

REZENDE, CE., LACERDA, LD., OVALLE, ARC., SILVA, CAR. and MARTINELLI, LA., 1990. Nature of POC transported in a mangrove ecosystem: A carbon stable isotopic study. Estuar. Coast. Shelf Sci., vol. 30, p. 641-646.

REZENDE, CER., 1993. Origem, transporte e destino da matéria orgânica na interface fluvio-marinha, sob diferentes condições de uso do solo e sua realação com o trânsito de poluentes metálicos na Baía de Sepetiba, RJ. 160p. (PhD Thesis) - Universidade Federal do Rio de Janeiro, Instituto de Biofísica Carlos Chagas Filho.

ROBERTSON, AI., 1986. Leaf-burying crabs: their influence on energy flow and export from mixed mangrove forests (Rhizophora spp.) in north eastern Australia. J. Experim. Mar. Biol. Ecol., vol. 102, nos. 2-3, p. 237-248.

SILVA, CAR., 1988. Distribuição e ciclagem de metais pesados em um ecossistema de manguezal na Baía de Sepetiba. (MSc Dissertation) - Universidade Federal Fluminense, Departamento de Geoquímica, 70p.

-, 1992. Formas e taxas de ciclagem do fósforo no ecossistema manguezal de Itacurussá. 100p. (PhD Thesis) - Universidade Federal de São Carlos, SP.

SILVA, CAR., LACERDA, LD. and REZENDE, CE., 1990. Metals reservoir in a red mangrove forest. Biotropica, vol. 22, no. 4, p. 339-345.

SILVA, CAR., LACERDA, LD., SILVA, LFF. and REZENDE, CE., 1991. Forest structure and biomass in a red mangrove stand in Sepetiba Bay-RJ, Brazil. Rev. Brasil. Biol., vol. 14, p. 21-25.

SILVA, LFF., LACERDA, LD., OVALLE, ARC., REZENDE, CE. and SILVA, CAR., 1993. Dinâmica de macrodetritos em um ecossistema de manguezal, Baía de Sepetiba, Rio de Janeiro, Brasil. Proc. III Simpósio de Ecossistemas da Costa Brasileira Subsídios a um Gerenciamento Ambiental, vol. I, p. 204-228.

SILVA, LFF., 1994. Balanço de macrodetritos em uma floresta de manguezal na Baía de Sepetiba, RJ. 76p. (MSc Thesis) Universidade Federal Fluminense.

STRICLAND, JDH. and PARSONS, TR. 1972. In A practical handbook of seawater analysis ( $2^{\text {nd }}$ ed.),Bulletin vol. 167, Fisheries Research Board of Canada, Ottowa, 310p. 
TAYLOR, DI. and ALLANSON, BR., 1995. Organic carbon fluxes between a high marsh and estuary, and the inapplicability of the Outwelling Hypothesis. Mar. Ecol. Progr. Ser., vol. 120, p. 263-270.

TWILLEY, RR., 1985. The exchange of organic carbon in basin mangrove forests in a Southwest Florida estuary. Estuar, Coast. Shelf Sci., vol. 20, 543-557.

,- 1988 . Coupling of mangroves to the productivity of estuarine and coastal waters. In JANSSON, BO. (ed.) Coastal-offshore Ecosystem Interactions. Springer-Verlag, Berlin, p. 155-180.
WILLIAMS, TM., WOLAVER, TG., DAME, RF. and SPURRIER, JD., 1992. The Bly Creek ecosystem study organic carbon transport within a n euhaline salt marsh basin, North Inlet, South Carolina. J. Exper. Mar. Biol. Ecol., vol. 163, no. 2, p. 125-139.

WOODROFFE, CD., 1985a. Studies on a mangrove basin, Tuff Crater, New Zealand. I. Mangrove biomass and production of detritus. Estuar, Coast. Shelf Sci., vol. 20, p. 265-280.

-. 1985b. Studies on a mangrove basin, Tuff Crater, New Zealand. II. The flux of organic and inorganic particulate matter. Estuar., Coast. Shelf Sci., vol. 20, p. 447-462. 